\title{
Applying the principles of Good Governance in the Efforts of Guiding Out-of-School Children at Social Service Offices Takalar Regency
}

\author{
Asri Ayu ${ }^{1}$, Risma Niswaty ${ }^{2}$, Muh. Darwis ${ }^{3}$, Sitti Hardiyanti Arhas ${ }^{4}$ \\ 1,2,3,4 Universitas Negeri Makassar \\ E-mail: aasriayu97@gmail.com
}

\begin{abstract}
This study aims to determine efforts to foster school dropouts at the Takalar District Social Service Office. This type of research is a descriptive study with a qualitative approach. Indicators used as benchmarks in this study are accountability, transparency, participation, and the rule of law of the bureaucratic apparatus. Data collection techniques are done through observation, interviews, and documentation. The data analysis technique used consists of data reduction, data presentation, and drawing conclusions. The results of the research on the application of the principles of Good Governance in the effort of developing school dropouts at the Takalar District Social Service Office show that governance at the Social Service Office is good enough
\end{abstract}

Key words: Principles, good governance, coaching.

\section{INTRODUCTION}

The public sector, as one of the elements of good governance, is closely related to the main tasks and functions of the institutions implementing state power, both efforts to realize good governance (Maryam, 2016; R Fajri, 2015). The role of the bureaucracy / public administration is to help the government formulate and implement public policies. Implementation of governance is very much needed in realizing good governance as one of the goals of the nation. The implementation of good governance is the main prerequisite in realizing the aspirations of the people in achieving the goals and ideals of the nation and state (Rustiarini \& Denpasar, 2016; Sedarmayanti, 2012; Supratman, 2018). In making this happen, it is necessary to develop and implement an appropriate system of participation, transparency, and accountability. Community participation in every process of making public policy is important as a reflection of the principles of democracy in a country. This becomes very appropriate when public participation is then promoted to be one of the principles that must be carried out by the government in an effort to realize good governance. The principle of participation in efforts to realize good governance carried out through public services is very much in line with the new view that is developing in an effort to improve public services by seeing the community not only as customers but as citizens who have a state as well as the government in it.Praktek good governance juga mensyaratkan adanya transparansi dalam proses penyelenggaraan pemerintahan secara keseluruhan (Ferdyant, ZR, \& Takidah, 2014; Randy \& Juniarti, 2013) . 


\section{Jurnal Office: Jurnal Pemikiran Ilmiah dan Pendidikan Administrasi Perkantoran Vol. 5, No. 2, July-December 2019, Hal 51-58}

Transparency is a very important concept and becomes increasingly important in line with the increasingly strong desire to develop good governance practices, by providing opportunities for the wider community to find out various information about the administration of government, so it can facilitate the efforts of the community in assessing the government's alignments to the public interest. The public can easily determine whether to provide support to the government, or vice versa, criticism and protests carried out so that the government is more pro-public interest. More than that, the right to obtain information is a human right of every citizen in order to be able to properly assess government performance. Transparency also has a relationship with public accountability. To create good governance, one of which is demonstrated by an accountable government bureaucratic service system, awareness among government employees about the importance of changing the image of public services is needed (Kamaruddin Sellang, 2016; Zeyn, 2011). Accountability is a degree that shows the responsibility of the apparatus for policies and public service processes carried out by the government bureaucracy.

The Takalar Regency Social Service Office is the executing element of government affairs which is the authority of the region, which is led by the head of the office which is located below and is responsible to the regent through the regional secretary. The task of the social service is to carry out the functions of formulating policies governing social affairs government affairs, implementing social affairs government policy, conducting evaluation and reporting of social affairs government affairs, as well as executing other functions given by the regent in relation to his duties and functions, must carry out governance in accordance with the principles of good governance, but the application of the principles of good governance in the effort of developing school dropouts at the Takalar District Social Service Office, has not been well implemented, this can be seen from the results of preliminary observations that have been done before, in terms of transparency information, where access to information regarding the guidance of school dropouts is still not good, this can be seen from the recapitulation of data on dropout children at the Takalar District Social Service Office who should receive assistance in 2018 recorded 287,472 people from nine sub-districts which is in the Takalar Regency, this explains that there is still a lack of information disclosure that is carried out in the effort of developing school drop-outs at the Takalar District Social Service Office, so that the community still lacks every aspect of policy issued by the government.

\section{METHOD}

This research uses descriptive qualitative research type. There are three stages in the research, namely the pre-research stage, the research stage, and the final stage (Niswaty, Juniati, Darwis, Salam, \& Arhas, 2019). The focus of this research is the application of the principles of good governance in the effort of fostering school dropouts at the Takalar District Social Service Office by using the four main principles of good governance proposed by (Sedarmayanti, 2012), is accountability, transparency, participation, rule of law of the bureaucratic apparatus. Sources of data in this study are primary data and secondary data. Data 
collection techniques used are interviews, observation, and documentation techniques, while checking the validity used is a member check. Data analysis techniques used are reduction, data condensation, data presentation, and verification.

\section{RESULT AND DISCUSSION}

The application of the principles of good governance in the effort of fostering school dropouts at the Takalar Regency Social Service Office, is the hope of the Indonesian people, especially in the people of Takalar Regency, in order to create good governance.

\section{Accountability}

Accountability refers to the development of a sense of public responsibility for the Takalar District Social Service Office, as a decision-maker in government, as well as to the owners (stakeholders). Specifically in the bureaucracy, accountability is an effort to create a monitoring system and control the performance of employees in the effort of fostering school dropouts as well as the existence of public accountability for each task given by the employer, so that employees have accountability in carrying out their duties.

The coaching effort undertaken by the Takalar Regency Social Service Office is to provide training and guidance in the form of training in sewing, automotive, cosmetology and others which can be applied in daily life. Social Service office staff conduct data collection and selection for school dropouts, to attend training in three places; Marsudi Putra Social Home, Teenage Nursing Home, Makkareso, and Nirannuang Social Home. The selection process for school dropouts by looking at several criteria, namely, children aged six years to senior high school age, dropout children who are unable to be financed by the parents concerned and get parental approval for training and guidance. In addition, the forms of employee accountability for the activities that have been carried out are also reported as well as possible in accordance with the directives of superiors

\section{Transparency}

Transparency, namely governance will be transparent to the people, both at the central and regional levels, transparency can be seen with easy, clear and comprehensive access to information so that the community can reach every facet of government policy issued by the Takalar District Social Service Office, the purpose of transparency is to build mutual trust between the government and the public where the government must provide accurate information for the public in need.

The form of transparency of employees in providing information about the existence of coaching efforts, usually social workers insert information related to the existence of coaching efforts if there is a meeting of parents of children who are in trouble with the law, the Office of Social Services is not bound by the provision of socialization about the existence of coaching efforts. Socialization is usually done once a year for 22 people with social welfare problems. In addition, the socialization held was not comprehensive for all sub-districts in Takalar Regency. There are several factors that become obstacles in the disclosure of information in the effort of 


\section{4| Jurnal Office: Jurnal Pemikiran Ilmiah dan Pendidikan Administrasi Perkantoran \\ Vol. 5, No. 2, July-December 2019, Hal 51-58}

fostering school dropouts is; there is no government procurement socialization fund, there is a lack of collaboration between the Sub-District Social Workers to provide information related to social welfare problems programs. Including efforts to foster dropout children organized by the Social Service and the lack of completeness of dropout data from every sub-district in Takalar District, due to lack of attention from the local government, this can be seen from the lack of parties who collect dropout data, matters this also becomes an obstacle in the preparation of activity programs, because the Office of Social Services is very lacking in terms of data on dropouts. Meanwhile, for those who encourage the smooth disclosure of information, namely the procurement of information dissemination, which is held once a year.

\section{Participation}

Participation is which involves community policy-making or formulation of plans made by the government, community participation is also seen from community involvement in the implementation of various government policies and plans, including supervision and evaluation, community involvement. The form of participation can be seen from the participation of employees in organizing efforts and the involvement of the community in the decision-making process.

The participation of Takalar Regency Social Service employees is quite active, this can be seen from the efforts of employees while carrying out their duties with great enthusiasm, serious employees in making selections for efforts to help drop out of school children, employees are also given official travel money, so as to increase employee enthusiasm. In addition, the community participates in efforts to foster out of school children through socialization by informing the surrounding environment about the efforts of coaching, and also supervises children who attend training by giving information to the child's parents, that the child has arrived at the place of guidance. The form of community involvement in decision making can also be seen from the stage of consultation of parents with the Social Service if their children will take part in training and coaching efforts. In addition, the community is also involved in the decision-making process through socialization which is held annually for 22 types of problem persons social welfare.

\section{The Supremacy of the Law of the Bureaucracy}

The rule of law of the bureaucratic apparatus means that there are clarity and predictability of bureaucracy relating to; legal certainty, there is a guarantee that the problem is clearly regulated, this can be seen from the existence of legal certainty guarantee for the development of school dropouts given by the Takalar District Social Service Office. The government provides guarantees to school dropouts who participate in coaching efforts that coaching is carried out safely. 


\section{Discussion}

\section{Accountability}

Accountability at the Takalar District Social Service Office refers to the form of employee accountability for the tasks assigned by superiors or leaders. Based on the results of interviews from various accountability informants in the effort of fostering school dropouts at the Takalar District Social Service Office, the Implementation of Good Governance Principles in Efforts to Foster School Drop Outs conducted by the Takalar District Social Service related to the principle of accountability has been done well, by employees Social Service Office by doing the form of accountability to superiors both verbally and in writing. In addition, in the process of carrying out the duties of employees in terms of carrying out coaching efforts have been done well, this can be seen from the efforts made in the process of selecting out of school children in accordance with the coaching criteria of children aged six years to graduate from high school, which are then placed in accordance with the results of the supervisor's recommendation.

\section{Transparency}

The principles of good governance in the effort of fostering school dropouts conducted by the Takalar District Social Service office, related to the principle of transparency are still carried out with less than the maximum, this can be seen from the disclosure of employee information related to the efforts to foster school dropout children are still lacking, procurement of socialization for Social Service programs for 22 people with social welfare problems are only carried out once a year, this is one of the factors that support the smooth implementation of the fostering program in addition to the existence of synergy between the Ministry of Social Affairs and the Social Service itself but, besides that there are many obstacles to information disclosure so that in terms of information disclosure related to the development efforts, it is still carried out less optimally, namely; indifferent attitude of school dropouts who do not really need information related to efforts to provide guidance, lack of funds to conduct social service programs, lack of cooperation from sub-district social workers, from various sub-districts to inform coaching efforts and lack of data on dropout children obtained by the Social Service due to lack of sub-districts that collect data about school dropouts.

\section{Participation}

The implementation of the principles of good governance in the effort to foster school dropouts associated with the principle of participation has been done quite well by the Takalar District Social Service office. this is done by inviting community leaders to take part in the socialization held by the Social Service office and then informing the community in accordance with the results of the discussion at the time of socialization if there is a socialization procurement to the sub-district carried out by the Takalar District Social Service. In addition, community involvement in the decision-making process was also seen during the selection 


\section{6| Jurnal Office: Jurnal Pemikiran Ilmiah dan Pendidikan Administrasi Perkantoran Vol. 5, No. 2, July-December 2019, Hal 51-58}

phase or the consultation stage of parents with employees of the Social Service before coaching efforts were made.

\section{The Supremacy of the Law of the Bureaucracy}

The implementation of Good Governance Principles in the Efforts of Guiding Out-ofSchool Children at the Takalar District Social Service Office related to the principle of the rule of law of the bureaucratic apparatus has been done well, this can be seen from the existence of guarantees of legal protection for school dropouts when attending training and coaching, In addition, Takalar Regency Social Service office employees are disciplined in carrying out their duties, Social Service employees are even very agile in finding ways to go down to select and collect data on children who have dropped out of school so that the application of sanctions to employees who commit undisciplined actions, until now not yet implemented.

\section{CONCLUSION}

Based on the results of the research presented in the previous chapter, it can be concluded that the Application of the Principles of Good Governance in the effort of developing school drop-outs at the Takalar District Office of the Service can be said to be quite good. It's just that of the four indicators of the Principles of Good governance, indicators of the Principles of Transparency need to be considered and improved by the Social Service of the Takalar Regency.

\section{REFERENCES}

Ferdyant, F., ZR, R. A., \& Takidah, E. (2014). Pengaruh Kualitas Penerapan Good Corporate Governance dan Risiko Pembiayaan terhadap Profitabilitas Perbankan Syariah. Jurnal Dinamika Akuntansi dan Bisnis. https://doi.org/10.24815/jdab.v1i2.3584

Kamaruddin Sellang. (2016). Administrasi dan Pelayanan Publik Antara Teori dan Aplikasi. In Akmen.

Maryam, N. S. (2016). Mewujudkan good governance melalui pelayanan publik. Jurnal Ilmu Politik dan Komunikasi.

Niswaty, R., Juniati, F., Darwis, M., Salam, R., \& Arhas, S. H. (2019). The Effectiveness of Leadership Functions Implementation in The Makassar Departement of Manpower. JPBM (Jurnal Pendidikan Bisnis dan Manajemen), $5(1), 1-10$.

R Fajri. (2015). Akuntabilitas Pemerintah Desa pada Pengelolaan Alokasi Dana Desa (Studi Pada Kantor Desa Ketindan, Kecamatan Lawang, Kabupaten Malang). 
Administrasipublik.Studentjournal.Ub ....

Randy, V., \& Juniarti. (2013). Pengaruh Penerapan Good Corporate Governance Terhadap Kinerja Keuangan Perusahaan yang Terdaftar di BEI 2007-2011. Business Accounting Review. https://doi.org/10.1080/00420986820080431

Rustiarini, N. W., \& Denpasar, U. M. (2016). Good Governance dalam Pengelolaan Dana Desa. Simposium Nasional Akuntansi.

Sedarmayanti. (2012). Good Governance: Kepemerintahan Yang Baik \& Good Corporate Governance: Tata Kelola Perusahaan Yang Baik. Bagian Ketiga, Edisi Revisi. Bandung: CV. Bandar Maju. https://doi.org/10.29040/jiei.v4i2.260

Supratman, D. (2018). Budaya Kerja Aparatur Sipil Negara dalam Rangka Good Governance menuju Birokrasi Berkelas Dunia. Jurnal Administrasi Publik, XIV(2), $101-108$.

Zeyn, E. (2011). Pengaruh Penerapan Good Governance dan Standar Akuntansi Pemerintahan terhadap Akuntabilitas Keuangan. Trikonomika. 
58| Jurnal Office: Jurnal Pemikiran Ilmiah dan Pendidikan Administrasi Perkantoran Vol. 5, No. 2, July-December 2019, Hal 51-58 